\title{
Date and Location for WCARP 2014 Now Set
}

The date and location of the next world adhesion congress have now been set. WCARP - 5th World Congress on Adhesion and Related Phenomena will be held from 7 to 11 September 2014 in Nara, Japan.

This four-day international event is gether leading international experts in the field of adhesion research for an exchange of ideas and information on the latest state of technology in this field.
The International Organising Committee is made up of the following organisations: the Adhesion Society (USA), the Adhesion Society in Spain (Spain), Beijing Adhesion Society (China), DECHEMA e.V. (Germany), Société Fran- çaise du Vide (France), the Society of Adhesion and Adhesives (United Kingdom), the Society of Adhesion and Interfaces (Korea).

For further information, please visit: www.adhesion.or.jp/wcarp

\section{Netzsch Acquires Bruker's Thermal Analysis Instruments Business in Japan}

N $\begin{aligned} & \text { etzsch Japan K.K. has acquired } \\ & \text { Bruker's Thermal Analysis instru- }\end{aligned}$ ments business in Japan.

Yoshio Shinoda, President of Netzsch Japan K.K., stated: “We are convinced that having a large R\&D and production site that understands the needs of the Japanese market is an excellent way to further develop our future business in Japan. With an additional 30 employees joining us from Bruker, Netzsch is now in a position to serve our Japanese customers even better, and we will further im- prove our outstanding reputation as the performance leader in Thermal Analysis instrumentation. This will boost the success that Netzsch has had in recent years in the Asia-Pacific region."

Sadao Ueki, President of Bruker AXS K.K., added: "It is a great benefit for our valued Thermal Analysis customers and employees to have the Thermal Analysis business now under the management of Netzsch Japan K.K, a global leader in high-performance Thermal Analysis instrumentation.
With the support of its headquarters in Germany, Netzsch will have a very successful future in Japan."

Until recently, Bruker, headquartered in Yokohama, had been distributing high-end Netzsch Thermal Analysis products in Japan in parallel with its own routine Thermal Analysis product line. As one of the leading countries in top level materials research and development, Japan is one of the most important markets for high-performance Thermal Analysis instrumentation.

\section{Robatech Takes Over Turkish Agency Ikiler Ticaret}

On 16 August, the owners of Ikiler Ticaret S.A. and Robatech signed an agreement on the takeover of $100 \%$ of the shares of Ikiler Company by the Robatech Group.

$T_{0}$ he he integration of the Turkish Sales and Service organisation into the Robatech Group demonstrates the importance of the Turkish and Iranian Market to the Swiss Management of Robatech. As a consequence of the takeover, the name of the company was changed to Robatech Tutkal Teknolojileri Sanayi Ticaret A .

Both companies will continue to be managed by Yunus Özden. Hakan Tanriöven will remain responsible for Sales, while Muharem Hündür will be in charge of the Technical Department. All of the 21 employees will be involved in the integration and want to contribute to further successful growth for the company.

Robatech AG, a producer of adhesive application systems for hotmelt and cold glue, now has 14 subsidiaries worldwide and is additionally represented by 32 agencies.

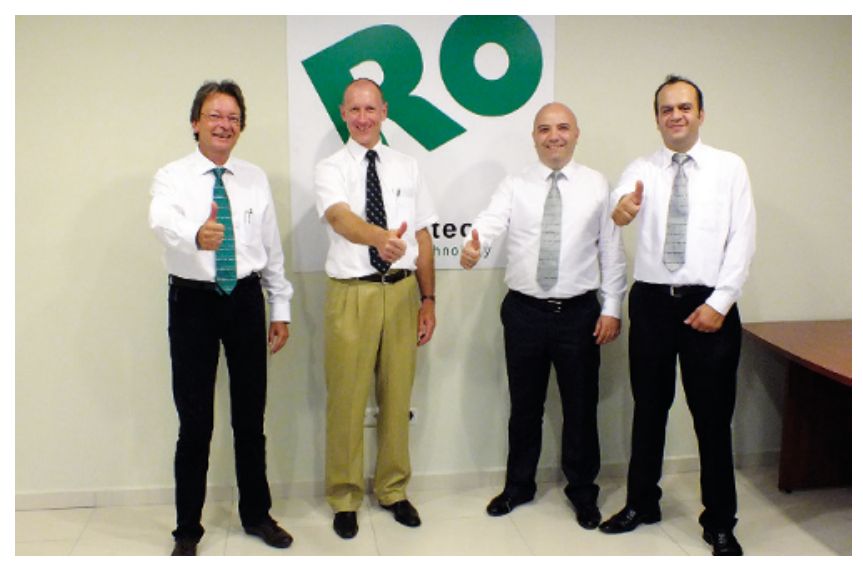

Yunus Özden, CEO of Robatech's Turkish agency; Marcel Meyer, President \& CEO Robatech Group; Hakan Tanriöven, Director of Sales; Muharem Hündür, Head of the Technical Department (from left) 